УДК: 7.036(4)

ББК: $71.4(3) ; 63.3(4 \mathrm{Aвс}) 6$

A43

DOI: $10.18688 /$ aa200-4-56

E. Höhn, L. Mešková

\title{
The Memory of the World War II in the Contemporary Art of Austria: The Political Voice of Art
}

Art is an opportunity to understand other world images. It freely crosses national and political boundaries, disrupts stereotypes. Many contemporary theoretical approaches move beyond the canon and engage in widespread political discourse. A new insight into the theory of culture promoted the view of artistic products as social constructs which are involved in the creation of secondary sign culture systems. Since then, the concepts of culture and art have ceased to be understood just as a higher social superstructure or a collection of artistic / literary works.

This process was preceded by intense theoretical research of culture and art. The boundaries of traditional perceptions began to change in the second half of the $20^{\text {th }}$ century, thanks to many literary and cultural theorists, representatives of various schools and artistic directions. Let us mention names such as Jurij M. Lotman, Roland Barthes, cultural memory theorists (Aleida and Jan Assmann), British Cultural Studies (Stuart Hall, Richard Hoggart), and cultural anthropology (Claude Lévi-Strauss). Culture was understood as a multi-layered process involving everyday life and different images of man in the perception and display of life: "In recent years, and in a more 'social science' context, the word 'culture' is used to refer to whatever is distinctive about the 'way of life' of a people, community, nation or social group. This has come to be known as the 'anthropological' definition" [7, p. 2].

What news does this approach to exploring culture bring? It means that in the information period a person is confronted with a number of phenomena and things, the authenticity of which we can't really examine; meanings are lost in a multitude of cultural practices. It turns out that art has become one of the means of the returning to the authenticity of the perception of the world and human existence. An important theoretical approach was provided by the French philosopher Paul Ricœur who was at the beginning of the interpretative turnover. It was Paul Ricœur who one of the first questioned the objectivity of a causal text, such as written history. According to this philosopher, the language of causality is not able to grasp phenomena directly. That is why historiography is threatened by instrumentalization [22, p. 37].

Literature has returned to the center of interest and become an important part of the symbolic practice of a man / people / group / nation. It deals with existential struggles and the handling of their meaning. The text becomes an individual and subjective code. By interpreting literary texts, a reader adapts to what was previously unknown. Ricœur draws attention to 
this in his book Theory of Interpretation: Discourse and Excessive Importance: "Interpretation in the endwishes to equate, make contemporary, assimilate in the sense of doing similar" [18, p. 122]. The Paul Ricœur's theory was later developed by Beatriz Sarlo, an Argentinian cultural theorist. In the text Tiempopasado Cultura de la Memoria y Giro Subjetivo- Una Discusión (2005) $)^{1}$, Sarlo speaks of two types of understanding: a) narrative and b) clarification. Sarlo puts historiography in the second group, because in it we observe the dangers of manipulation in favor of causality. This avoids a subjective experience which can be objectified by memory; for example, by remembering as a form of narrative identity, i.e. a literary text. Memory, though, is a subjective experience, but there is no "moral reason why these questions should also be omitted" [20, p. 346]. Apart from professional writers literature, a subjective experience can also be expressed by the people who have survived the historical event. That is why it is not a journey of knowledge, but of acquaintance. Such narratives are the literary or memorial texts of authors who have experienced a certain phenomenon, which, in our case, is the identity of Austria. Through those texts it is often possible to maintain the meanings critical to society [10, p. 91].

We have shown that the literary text as a secondary language system becomes an important part of cultural practice and therefore has a discursive character. The culture, in this context, is involved in the relations of power and domination of a certain society, group, or nation. Even in the form of the still accepted rules and values, it can contribute to the stabilization and consolidation of the order of domination - here we are talking about its affirmative function. This discourse of art occurs when it is possible to establish the models of meaning and values as generally valid; aesthetic values have an educative and ethical function [14, pp. 36-38]. At that time, the social and political order is legitimated and consolidated. However, in case when conventional customs, attitudes and values of society are challenged by art, we talk about the subversive function of art. Through cultural practice, the canon is disturbed, the mirror is set to the political, ideological, and media impact. Art is thus a reservoir of nation's memory; it affects the creation of identity and is a separate form of relation to the past. An example of this is the German $19^{\text {th }}$-century literature, which encouraged the Germans to mobilize their forces against Napoleon ${ }^{2}$.

Let's look at the role of the Austrian literature in the second half of the $20^{\text {th }}$ century. The Austrian literature contributed to its critical potential and still contributes to the creation of the identity of this European country. It disrupts the image of Austria as an idyllic Alpine country inhabited by charismatic people. Moreover, the ideal state is on the inside troubled by conflicts which origins are to be sought in the near past. Among the historical and political events that contributed to the discussion of the country's past, the Moscow Declaration (1943) should be mentioned first. In it, the Allied Powers (USA, Great Britain, France and the Soviet Union) designate Austria as the first free country to fall victim to Nazi aggression and later to be liberated from German domination. As a result of the Moscow Declaration, the mood of

We used the translation in the German language under the name Rhetorik der Zeugenschaft.

Die Hermannsschlacht, a theatre play by German dramatist Heinrich von Kleist. The play originated in 1807 after the defeat of Prussia. Kleist features the Germans' victory over the Romans in a battle in the Teutoburg Forest. 
forgetting the past was dominant in the Austrian postwar society. We can say that in the process of shaping a new Austrian identity, the "Victim Thesis" had a very important role during the Third Reich. According to Zeyringer [25], it served not only as means of consciousness of national independence, but as means of getting rid of the guilt of the Nazi period. In the History of Austria [23], we can read that many Austrians have accepted the "Victim Thesis" as a convenient and comfortable view of dealing with their own past.

Also, in order to suppress their history, the right-wing forces in Austria had a strong voice in the second half of the $20^{\text {th }}$ century, which led to several political affairs. The most famous of them is the Waldheim affair, as well as the scandals associated with the FPÖ Chairman Jörg Haider. After nearly forty years of economic growth, a certain change occurred in the country. It was accompanied by a deteriorating economic situation, a strengthening of the Austrian ecological movement, increasing criticism of the church and an increase in scandals. The positive image of Austria suddenly changed to the image of a scandalous republic [6]. In 1986, when Kurt Waldheim, the former UN Secretary-General from 1972 to 1981, accepted the candidacy for the Federal President of Austria, accusations of silencing his Nazi past systematically began to appear in the media. Waldheim was accused, in particular, of actively operating in the German army in the Balkans during the Second World War. Waldheim's affair led to the extensive debate on the role of Austria in the Second World War and the reassessment of the original victim story, which redefined the Austrian identity [3].

It was in 1986 when director Claus Peymann came to the Burgtheater in Vienna. Kurt Waldheim was already elected for president, and Jörg Haider, a controversial right-wing politician, became the chairman of the FPÖ. In the context of the right-wing atmosphere in the country, Claus Peymann, on the occasion of the $50^{\text {th }}$ anniversary of Austria's "Anschluss" to the Third Reich, asked the dramatist Thomas Bernhard to write the play Heldenplatz (1988). Bernhard reminded Austrians of the Nazi history of their country. Provocative is its name Heldenplatz is the name of a well-known Viennese town square, where about 200,000 people welcomed Adolf Hitler in March, 1938. All of these processes can be perceived as the first steps towards understanding the complex past and the broad discussion of one's own identity that persists until today.

Not only Thomas Bernhard, but also other Austrian artists and writers of the second half of the $20^{\text {th }}$ century act hard on the address of Waldheim, Haider, FPÖ and others. One should mention authors of the middle generation, such as Elfriede Jelinek and Peter Handke or Hans Lebert (Die Wolfshaut, 1960), Ilse Aichinger (Die Größere Hoffnung, 1948) and Gerhard Fritsch (Moos auf Steinen, 1956) before them. In the 90s, the years of the rise of the right-wing forces, Wolfgang Keller became well known for his instalation which "threw the first stone" near the wall of St. Stephen's Cathedral in Vienna (2000). His act became the mechanism of launching the famous Viennese protest of cultural figures against the arrival of Jörg Haider into the ruling coalition. Elfriede Jelinek, the Nobel Prize winner for literature, writers such as Erich Fried, Elisabeth Reinhardt, Schoschana Rabinovici and others have been also involved in the creating a critical discourse on the Austrian political scene.

In 2018, the film The Interpreter, by the Slovak director Martin Šlík, was launched in Slovakia and Austria. Its main heroes are two old gentlemen who travel across Slovakia. They want to know the truth about their own past. Georg, the70-year-old Austrian and the son of 
a former SS supervisor, travels across Slovakia with Ali Ungar, whose parents were murdered by the order of Georg's father during the Second World War. Deep, unsolved problems of both begin to emerge and change their identities. The Interpreter was inspired by the book of the Austrian writer Martin Pollack Der tote im Bunker (2004). The author wrote about the Nazi past of his father, who as a commander of special SS sections, was stationed in the Slovak town of Ružomberok in 1944, where he ordered the murder of dozens of people.

The new millennium of Austrian literature is also part of the critical discourse. A young generation of authors follows their predecessors. Many texts are more often associated with questions of personal identity. This is the case, for example, in works by Thomas Glavinić ( $\left.{ }^{*} 1972\right)$ as Das bin doch ich (2007), Die Arbeit der Nacht (2006) or Das größere Wunder (2013). Similarly, in the novel Es geht uns gut (2005) by Arno Geiger ( $\left.{ }^{\star} 1968\right)$, which was in 2005 awarded with the most prestigious literary prize of German speaking countries — the German Book Prize.

However, we find the first socio-critical, subversive issue only in the second group of contemporary Austrian writers, especially authors with a migrant background. The novel by Robert Schindel (*1944) Gebürtig (1992) takes place in the 1980s in Vienna. Composer Hermann Gebirtig emigrated during the Nazi regime from Vienna to New York. Now he is coming back to testify in the trial with Egger, former supervisor in the Austrian concentration camp Ebensee. However, when Egger is deprived of guilt by the court, Hermann doesn't see his future in Vienna any longer and decides to return to the US. He knows that in Vienna of the Kurt Waldheimera there is no place for him. Waldheim's affair is also the central theme of the other novel by this writer, Der Kalte (2013). Another Austrian writer of Jewish origin, Doron Rabinovici $\left({ }^{*} 1961\right)$ also deals with the question of Jewish identity through the story of the second post-war generation in the novel Suche nach M. (1997). It raises the problem of the first post-war generation which kept silent about the war, transferring the fate of the victims and criminals to their children. In the 1990s, Robert Menasse $\left({ }^{\star} 1954\right)$, another representative of the writers with Jewish origins, contributed remarkably to the topic of Waldheim and Haider. He was particularly involved in his essays rather than in novels. Under the title It was Austria, the selection from Menasse's essay also reached the Slovak reader in 2009.

An important group of Austrian contemporary literature consists of writers of migrant origin; for example, Dimitre Dinev, Julia Rabinowich, Vladimir Vertlib, Denis Mikan, Radek Knapp, and others. The collapse of the Eastern Block after 1989 is the main theme of these writers. Of these authors the most outstanding are: Dimitre Dinev $\left({ }^{\star} 1968\right)$, a writer, screenwriter and dramatist of Bulgarian origin (Engelszungen, 2003), Radek Knapp ( $\left.{ }^{\star} 1964\right)$ of Polish origin (Herrn Kukas Empfehlungen, 1999), followed by Vladimir Vertlib $\left({ }^{\star} 1966\right)$, an author of Russian-Jewish origin who depicted the escape from the Russian totalitarian regime in the novel Schimons Schweigen (2012). Julia Rabinowich $\left({ }^{\star} 1970\right)$ from St. Petersburg portrayed the life of emigrants in Austria in her debut novel Spaltkopf (2008). At a time of political controversy of 2000, this generation of writers and journalists (Isolde Charim, Robert Misik and Doron Rabinovici) organized the "Democratic offensive". They opposed the FPÖ election program which restricted the rights of foreigners in Austria. Schoschana Rabinovici, the mother of the writer Doron Rabinovici, published an autobiographical book Dank meiner Mutter in 1998, which described the traumatic events of the Jewish ghetto in Vilnius, the capital city of Lithuania and the deportation to the Stutthof concentration camp near Gdansk, the Polish port city. 
The impact of this artistic discourse in Austria can be traced especially to its capital city of Vienna, where several World War II memorial sites have been unveiled over the last decades. As an example, The Archives of the Austrian Anti-National Socialism Documentation at the Wipplingerstraße, The Jewish Museum at the Judenplatz, The Brigittenau Gymnasium in Karajangasse in the twentieth district of Vienna. In the gymnasium, prisoners were assigned to be transported to the Dachau concentration camp. Among them, for example, Bruno Kreisky, former chancellor of Austria (1970-1983). Also important is a memorial at Steinhof Hospital, Gedenkstätte Steinhof, where about 800 sick and disabled children died in the years 1940-1945.

Only in 2018, the Vienna University organized a great number of exhibitions, lectures and book presentations on the Second World War. As an example, let us mention the Sobibór concentration camp in Poland, the Slovak national uprising against fascism (under the name Let our righteous thing live!). In cooperation with the Institute of Contemporary History of the University of Vienna, in the university library, a traveling exhibition of Israeli Holocaust memorial sites was installed in the months of April to June 2018 under the title Wie war es menschlich möglich? (How Was It Humanly Possible?). The Institute of Contemporary History of the University of Vienna participates in the research of Austrian anti-Semitism.

It turns out that art is the medium by which society, depending on the current situation, predefines history. In our opinion, this is the point of the contribution of culture to social practice.

\section{References}

1. Bachtin M. Estetika slovesnej tvorby. Bratislava, Tatran Publ., 1988. 451 p. (in Slovak).

2. Benczeová B. Postmoderná filozofia kultúry. Bratislava, Univerzita Komenského Publ., 2014. 83 p. (in Slovak).

3. Cheie L.; Pascu-Ringler E. Österreichische Literatur. Wien, Praesen Verlag Publ., 2018. 252 p. (in German).

4. Dörner A.; Vogt L. Literatursoziologie. Fernsehwissenschaft. Theorie - Geschichte - Analyse. Wiesbaden, Springer VS Publ., 2013. 337 p. (in German).

5. Geiger A. Es geht uns gut. München, Carl Hanser Verlag Publ., 2005. 389 p. (in German).

6. Gehler M. Die Affäre Waldheim: Eine Fall Studie zum Umgang mit den NS Vergangenheit in den späten achtziger Jahren. Österreich im 20. Jahrhundert: ein Studienbuch in zwei Bänden: Vom Zweiten Weltkrieg bis zur Gegenwart, vol. 2. Wien, Böhlau Verlag Publ., 1997, pp. 355-414 (in German).

7. Hall S. The Work of Representation. Representation: Cultural Representations and Signifying Practices. London; California, SAGE Publ., 1997, pp. 13-74.

8. Hall S. Die zwei Paradigmen der Cultural Studies.Widerspenstige Kulturen. Cultural Studies als Herausforderung. Frankfurt am Main, Suhrkamp Publ., 1999, pp. 13-42 (in German).

9. Hall S. Kodieren/Dekodieren. Grundlagentexte zur Fernsehwissenschaft. Theorie - Geschichte - Analyse. München, 2002, pp. 105-124 (in German).

10. Javorčíková J. Žánrové paralely v dramatickej tvorbe Eugena O’Neilla. České Budějovice, Jihočeská univerzita Publ., 2008. 203 p. (in Slovak).

11. Jelinek E. Hry. Bratislava, Divadelný ústav Publ., 2014. 367 p. (in Slovak).

12. Knapp R. Co mi pán Kuka nakukal. Praha, Kalich Publ., 2008. 205 p. (in Czech).

13. Lotman J. M. Text a kultúra. Bratislava, Archa Publ., 1994. 100 p. (in Slovak).

14. Mistrík E. Estetická výchova ako nástroj sebareflexie. Bratislava; Oulu, Pedagogická fakulta UK, Pedagogická fakulta Univerzity v Oulu Publ., 2016. 268 p. (in Slovak).

15. Nünning A. Literatur- und Kulturtheorie. Stuttgart, Metzler Verlag Publ., 2001. 954 p. (in German).

16. Rabinovici D. Suche nach M. Frankfurt am Main, Suhrkamp Publ., 1997. 269 p. (in German).

17. Rabinovici S. Dank meiner Mutter. Frankfurt am Main, Alibaba Verlag Publ., 1994. 251 p. (in German).

18. Ricœur P. Teória interpretácie: Diskurz a prebytok významu. Bratislava, Archa Publ., 1996. 135 p. (in Slovak).

19. Rieger D. Literaturwissenschaft als Kulturwissenschaft - aus der Perspektive eines Literaturwissenschaftlers. Kulturwissenschaftliche Literaturwissenschaft, 2004, pp. 97-114 (in German). 
20. Sarlo B. Rhetorik der Zeugenschaft. Lateinamerikanische Kulturtheorien. Konstanz, University Press Publ., 2015, pp. 343-365 (in German).

21. Schmidt-Dengler W. Bruchlinien. Salzburg; Wien, Residenz Publ., 1996. 559 p. (in German).

22. Sivák J. Paul Ricœur. Bilancia a výzvy. Filozofia, 2006, vol. 61, no.1, pp. 30-45. Available at: http://www. klemens.sav.sk/fiusav/doc/filozofia/2006/1/30-45.pdf (accessed 18 December 2018).

23. Veber V. Déjiny Rakouska. Praha, Lidové noviny Publ., 2002. 727 p. (in Czech).

24. Vertlib V. Šimonovo mlčení. Praha, Kalich Publ., 2013. 237 p. (in Czech).

25. Zeyringer K. Innerlichkeit und Öffentlichkeit. Österreichische Literatur der achtziger Jahre. Tübingen, Francke Publ., 1992. 305 p. (in German).

Title. The Memory of the World War II in the Contemporary Art of Austria: The Political Voice of Art

Authors. Ludmila Mešková - Doc., Ph. D., head of department. Matej Bel University, Tajovského 40, 97401 Banská Bystrica, Slovakia. ludmila.meskova@umb.sk

Eva Höhn - Mag., Ph. D., assistant professor. Matej Bel University, Tajovského 40, 97401 Banská Bystrica, Slovakia.eva.hohn@umb.sk

Abstract. The article is devoted to the understanding of art as the medium through which society, depending on the current situation, redefines its history. In our opinion it is precisely at this point that the contribution of cultural theory to social practice lies. The social discourse of the Holocaust and the Second World War, which was reinforced in Western Europe at the end of the $20^{\text {th }}$ century, will also give rise to art. A great part of this process is due to the current Austrian literature. The voice of the art in Austria grows in power always when conservative, right-wing forces are on the rise. The art installation of Wolfgang Keller "who threw the first stone" near the wall of St. Stephen's Cathedral in Vienna (2000) became the trigger mechanism of the famous Viennese protest of cultural figures against the coming to power of Jörg Haiders right-wing party. Earlier, in the year 1988, writer Thomas Bernhard responded with the play Heldenplatz to the affair of Austrian President Kurt Waldheim. Elfriede Jelinek, the Nobel Prize winner for literature, often criticized the Austrian right-wing party FPÖ in her work. The Holocaust debate has an extraordinary influence on the Austrian cinema as well as on the cinematography of the countries involved in the orbit of Austrian art. One of the most recent examples is Tlmočník (2018), the movie about Austria and Slovakia during the Second World War by Slovak director Martin Šulík.

Keywords: cultural turn, interpretative turn, cultural memory, contemporary Austrian art and literature, Slovak and Austrian history

Название статьи. Вторая мировая война в современном искусстве Австрии: политический голос искусства

Сведения об авторах. Мешкова Людмила — Ph. D., доцент, начальник отдела. Университет Матей Бел, Tajovského 40, 97401 Баньска Быстрица, Словакия. ludmila.meskova@umb.sk

Хон Ева — магистр, Ph. D., доцент. Университет Матей Бел, Tajovského 40, 97401 Баньска Быстрица, Словакия. eva.hohn@umb.sk

Аннотация. Искусство наряду с историографией является крупнейшим резервуаром памяти нации. Оно влияет на формирование самоидентичности и представляет собой отдельную форму отношения к прошлому (Ян Ассманн, Алейда Ассманн). Это среда, посредством которой общество в зависимости от текущей ситуации пересматривает историю. По мнению авторов статьи, именно в этом и заключается вклад теории культуры в социальную практику. Социальный дискурс о холокосте и Второй мировой войне, набравший силу в Западной Европе в конце XX в., также породил своё искусство. Большая часть этого процесса связана с современной австрийской литературой. Голос искусства в Австрии усиливается всегда, когда консервативные, правые силы находятся на подъёме. Инсталляция Вольфганга Келлера, «бросившего первый камень» у стены собора Святого Стефана в Вене (2000), стала спусковым механизмом знаменитого венского протеста деятелей культуры против прихода к власти правого радикалиста Йорга Хайдера. Ранее, в 1988 г., писатель Томас Бернхард ответил пьесой «Хельденплац» на дело президента Австрии Курта Вальдхайма. Лауреат Нобелевской премии по литературе Эльфрида Елинек часто критикует австрийскую правую партию FРӦ в своих работах. Дебаты о холокосте имеют необычайное влияние в кинематографии Австрии, а также стран, вовлечённых в орбиту австрийского искусства. Среди последних примеров - фильм словацкого режиссера Мартина Шулика «Переводчик» (2018) об Австрии и Словакии во время Второй мировой войны.

Ключевые слова: культурный поворот, интерпретативный поворот, культурная память, современное австрийское искусство, современная австрийская литература, словацкая и австрийская история 